\title{
Den danske model til eksamen - et casestudie af CSC-konflikten
}

Ilsøe, Anna

Published in:

Tidsskrift for Arbejdsliv

Publication date:

2012

Document version

Også kaldet Forlagets PDF

Citation for published version (APA):

Ilsøe, A. (2012). Den danske model til eksamen - et casestudie af CSC-konflikten. Tidsskrift for Arbejdsliv, 14(2),

31-48. http://www.nyt-om-arbejdsliv.dk/images/pdf/2012/nr2/tfa2_2012_031_048.pdf 


\section{Den danske model til eksamen}

\section{- et casestudie af CSC-konflikten}

\section{Anna Ilsøe}

Antallet af konflikter på det danske arbejdsmarked har vist en faldende tendens over de seneste 15 år. Imidlertid begynder vi nu at se et større pres på danske lønninger som følge af øget international konkurrence og et højere uddannelsesniveau i ikke-vestlige lande. Det betyder også, at vi ser konflikter, der har deres rod i arbejdsgivernes ønske om en væsentlig lønnedgang blandt deres medarbejdere. Her er et af de tydeligste eksempler den langvarige konflikt mellem IT-virksomheden CSC og fagforeningen PROSA. På baggrund af dokumentstudier og interview med de implicerede parter undersøger denne artikel, hvor CSC-konflikten kan siges at afvige fra den danske model for regulering af arbejdsmarkedet. I forlængelse heraf diskuteres, om konflikten peger på nogle generelle problemer i den danske models tilpasningsdygtighed på et globaliseret arbejdsmarked.

$\mathrm{I}^{\mathrm{t}}$ foråret 2011 fandt en bemærkelsesværdig konflikt sted på det danske arbejdsmarked. Det var konflikten mellem den amerikansk ejede IT-virksomhed CSC og fagforeningen PROSA. Striden på virksomheden stod om to overenskomster, som parterne havde søgt at genforhandle siden 2009. Konflikten var bemærkelsesværdig af flere grunde. For det første var det en langstrakt konflikt, der begyndte med CSC's lockout af 120 medarbejdere d. 9. februar og sluttede d. 27. juni, hvor CSC indgik en ny overenskomst - ikke med PROSA, men med HK/Privat - og de fleste strejkende eller lockoutede medarbejdere vendte tilbage til deres arbejde (se Figur 1 for en kort oversigt over forløbet). For det andet gav konflikten anledning til en diskussion af den danske model som sådan og dens levedygtighed i fremtiden. PROSA's medlemmer havde i en længere periode haft en stærk forhandlingsposition i forhold til CSC's ledelse, og de havde brugt den til at fastholde nogle for branchen gunstige løn- og arbejdsvilkår. CSC's ledelse ønskede imidlertid at revidere disse vilkår på grund af den tiltagende konkurrence i IT-branchen.

Mange har sammenlignet CSC-konflikten med konflikten på BT i 1977, hvor typograferne måtte gå væsentligt ned i løn- og arbejdsvilkår efter et langstrakt konfliktforløb. Nye trykkerformer betød, at typografernes tekniske monopol var under opbrud, og dermed mistede de også deres tidligere forhandlingsstyrke (Lundrup 2008). I dag betyder den globale teknologiske og uddannelsesmæssige udvikling inden for IT-branchen, at mange jobfunktioner inden for IT kan outsources, og at forhandlingspositionen for disse grupper dermed svækkes.

Formålet med denne analyse er at undersøge, hvor konflikten mere specifikt kan siges at afvige fra den danske model. I forlængelse heraf diskuteres, om disse afvigelser peger 
på nogle generelle udfordringer for den danske model i takt med globaliseringen. Artiklen er struktureret på følgende måde: Først beskrives baggrunden for konflikten. Der- næst defineres begrebet 'den danske model', og undersøgelsens metode præsenteres. Efter selve analysen afsluttes artiklen med en samlet konklusion og diskussion.

Figur 1. Oversigt over forløbet

\section{Baggrund}

1973: PROSA indgår overenskomst med det statsejede Datacentralen.

1996: Datacentralen bliver købt af den globale IT-koncern CSC. CSC ønsker individuelle lønvilkår, men det får de ikke igennem over for PROSA.

2009: Udløb af de gamle overenskomster mellem CSC og PROSA (PROSA-CSC/dk og PROSACSC/profot). Forhandlinger om en ny samlet overenskomst indledes, men de bryder sammen, da CSC vil flytte udløbsdatoen for overenskomsten fra 1. juni til 1. marts. PROSA sender sit første konfliktvarsel.

\section{Optakt og konflikt 2011}

4. januar: Forhandlingerne genoptages. CSC stiller krav om at fjerne tryghedsaftalerne, øge arbejdstiden og ændre lønvilkårene for 700 ansatte på overenskomst med PROSA. Tryghedsaftalerne sikrer de ansatte et forlænget opsigelsesvarsel og økonomisk kompensation ved fyring.

9. februar: CSC lockouter 120 medarbejdere.

18. februar:PROSA opsiger en fredsaftale for 400 medarbejdere, der arbejder på de kørende systemer, pr. 1. juni og varsler strejke for 49 medarbejdere pr. 28. februar.

24. marts: Arbejdsretten afgør, at fredsaftalens bestemmelser vedrører hele medarbejdere og ikke blot enkelte arbejdsopgaver. Det betyder, at kun fem af de 49 ansatte udtaget til strejke må strejke. CSC må fortsat lockoute 116 af de 120 lockoutede ansatte.

13. april: Ca. 25 medarbejdere vælger at forlade deres arbejde. Arbejdsretten hastebehandler sagen dagen efter og erklærer strejken for overenskomststridig.

24. maj: Faglig voldgift. CSC må kun have 10 vikarer ansat. CSC må dog gerne hyre eksterne konsulenter.

28. maj: CSC og PROSA bliver enige om en ny overenskomst efter tre døgns forhandlinger. Det bliver dog afvist på et PROSA-medlemsmøde at sende den til afstemning blandt medlemmerne.

31. maj: Forligsinstitutionen fremsætter mæglingsforslag og kræver det sendt til afstemning blandt PROSA's medlemmer. Dom i arbejdsretten: CSC må ikke sætte konfliktvarslede til at oplære afløsere, men allerede oplærte må gerne blive.

1. juni: Over 300 PROSA medlemmer går i strejke.

12. juni: Forligsmanden meddeler, at PROSA's medlemmer har stemt nej til mæglingsforslaget.

23. juni: Dom i arbejdsretten. CSC er frigjort fra to af deres overenskomster med PROSA.

24. juni: $\quad$ PROSA's medlemmer beslutter at indstille strejken på CSC.

27. juni: $\quad$ Flertallet af de lockoutede og strejkende medarbejdere vender tilbage til deres arbejde på CSC. CSC indgår overenskomst med HK/Privat. 


\section{Baggrund}

Den internationale konkurrence har længe været en udfordring for det danske arbejdsmarked og reguleringen af danske løn- og arbejdsvilkår. Den intensiveres til stadighed, og derfor må danske virksomheder hele tiden finde nye og mere effektive eller fleksible måder at producere eller servicere på. Det danske lønniveau ligger højt i international sammenligning, og mantraet har derfor været, at vi i Danmark skal konkurrere på kvalifikationer og ikke på løn. Imidlertid kan man nu observere et større pres på danske lønninger end tidligere. Den seneste lønstatistik fra DA viser således, at lønstigningstakten fra 2010-2011 er den laveste i statistikkens levetid (DA 2011b). Udover presset fra den nuværende finansielle og økonomiske krise kan den lavere lønstigningstakt måske også forklares med den større konkurrence fra højtkvalificeret arbejdskraft i lande uden for den vestlige verden (Contractor m.fl. 2011). Uddannelsesniveauet er stigende i de nye økonomier såsom Indien og Kina, og derfor kan flere og flere jobfunktioner outsources og klares for en meget lavere løn end i Europa. Også den teknologiske udvikling bidrager til, at flere funktioner end tidligere kan flyttes ud. Man kan derfor ikke længere regne med, at en særlig højt kvalificeret kernearbejdskraft i Danmark går helt fri af lønpres og udflytning af arbejdspladser. Det betyder også, at forhandlingspositionen for denne gruppe på det danske arbejdsmarked er under forandring.

En af de brancher, hvor man først mærker effekten af nye hardware- og softwaremuligheder på udflytningen af jobs, er i sagens natur IT-branchen. Beskæftigelsesudviklingen på IT-området er gået meget op og ned $i$ det seneste årti. Omkring årtusindeskiftet var der så stor en mangel på IT-specialister i Danmark, at regeringen indførte en 'fast track'-ordning for udenlandske IT-specia- lister, så de kunne komme hurtigere til Danmark (Hansen m.fl. 2010). På dette tidspunkt nåede IT-beskæftigelsen i Danmark ifølge tal fra ATP op på ca. 105.000 (Bjørsted \& Knigge 2009). Siden er den generelle beskæftigelse i IT-branchen faldet, men nyere beregninger baseret på DREAMregisteret viser, at der er store forskelle på beskæftigelsesudviklingen inden for de enkelte grupper i IT-branchen (Baadsgaard \& Hansen 2011). Der kan faktisk konstateres en let stigning i beskæftigelsen for IT-service og IT-konsulentvirksomhed, mens beskæftigelsen i IT-industri og IT-handel går stærkt tilbage (ibid.).

Udviklingen i IT-beskæftigelsen i Danmark siden årtusindeskiftet peger på, hvor kompleks konkurrencesituationen er på området. Nogle specialiserede jobfunktioner flyttes ud på grund af pris eller mangel på kompetencer, mens andre holdes i landet og varetages af importeret arbejdskraft. Denne komplekse konkurrencesituation danner også baggrund for konflikten på ITvirksomheden CSC. Ledelsen på CSC havde gennem flere år forsøgt at forhandle sig frem til lavere omkostninger og mere fleksibilitet for at opnå en mere konkurrencedygtig virksomhed. Ifølge beregninger fra PROSA mødte ledelsen op til forhandlingerne i januar 2011 med krav om en samlet nedgang i vilkår på $30 \%$ (PROSA 2011). Under en lignende konflikt i marts 2011 mellem ledelse og assurandører hos forsikringsselskabet Tryg blev medarbejdersiden - ifølge Finansforbundets beregninger - også mødt med krav om en voldsom nedgang i løn- og arbejdsvilkår. Assurandørerne endte med at stemme ja til et forlig om en mindre lønnedgang i april. Omdrejningspunktet i de følgende afsnit vil være, hvorfor CSC's ledelse og fagforeningen PROSA ikke kom i mål med et lignende forlig. Først vil vi dog vende blikket mod den danske model og dens bestanddele. 


\section{Den danske model - teoretiske perspektiver og forskningsspørgsmål}

Begrebet 'den danske model' er i de senere år blevet brugt i forbindelse med mange forskellige diskussioner af det danske arbejdsmarkeds tilstand. Dette gælder ikke mindst debatter om arbejdsmarkedet i TV, aviser og fagblade. Imidlertid henviser begrebet oprindeligt til en række grundlæggende karakteristika ved den måde, det danske arbejdsmarked er reguleret på. Jesper Due og Jørgen Steen Madsen definerer begrebet ud fra i alt seks dimensioner eller særtræk ved det kollektive aftalesystem i Danmark (Due m.fl. 1993, 13-14; Due \& Madsen 2006, 28-30):

\section{Høje organisationsprocenter og høj over- enskomstdækning}

2. Nationalt samordnede overenskomstforhandlinger

3. Sammenhængende system med flere niveauer

4. Konflikt og konsensus

5. Voluntarisme: Selvregulering med begrænset lovgivning

6. Aftalesystemet og det politiske system

Overordnet set henviser begrebet til det faktum, at det danske arbejdsmarked først og fremmest er reguleret via kollektive aftaler forhandlet på plads mellem organisationer på hhv. arbejdsgiver- og arbejdstagerside (5. dimension). Lovgivning spiller kun en begrænset rolle, hvilket hænger sammen med, at vi stadig har relativt høje organisationsgrader og en relativt høj overenskomstdækning blandt arbejdstagere og arbejdsgivere (1. dimension). De forhandlende parter møder frem til forhandlingsbordet med veletablerede forhandlingsmandater, og det politiske system behøver derfor ikke i udgangspunktet at blande sig i reguleringen (6. dimension). Den nationale samordning af overenskomstforhandlingerne betyder, at konflikterne koncentreres omkring en samlet dato for overenskomstfornyelse, den 1. marts i den private sektor, og at der er fredspligt i perioderne mellem overenskomstfornyelserne (2. dimension). Samordningen betyder også, at forligsmanden kan sammenkæde forlig i den private sektor til et samlet mæglingsforslag, der sendes til afstemning blandt alle berørte medlemmer. Hvis flertallet af medlemmerne stemmer ja, så kommer alle overenskomstområder i hus med et forlig. Denne samordning er en af de afgørende årsager til det relativt lave konfliktniveau i Danmark.

En anden årsag til det lave konfliktniveau er de konsensusbaserede forhandlingsrelationer, der er opbygget mellem de modstående parter på det danske arbejdsmarked (4 . dimension). Flere undersøgelser har vist, at vi finder høj tillid mellem parterne på det danske arbejdsmarked såvel centralt som lokalt (Due \& Madsen 1996; Navrbjerg m.fl. 2010; Ilsøe 2009). Det er af stor betydning både når overenskomsterne skal fornys, og når overenskomsterne implementeres ude på den enkelte virksomhed. I dag rummer mange overenskomster muligheder for lokale forhandlinger. Det gælder ikke mindst Industriens Overenskomst, hvor løn og arbejdstid i vidt omfang forhandles lokalt (3. dimension). Her er den høje grad af tillid mellem danske ledere og tillidsrepræsentanter afgørende - ikke mindst når det gælder om at undgå overenskomststridige arbejdsnedlæggelser. Man er enige om at være uenige - at besidde modstridende interesser - men også om kompromisets nødvendighed. Det betyder, at indholdet af de aftaler, der forhandles, ofte kommer begge parter til gode (Ilsøe 2009). Hvis ikke kompromiserne giver fordele for både den ene og den anden part, så er det svært at bevare en konsensusbaseret forhandlingsrelation.

Når begge forhold er til stede - konsen- 
susbaserede forhandlingsrelationer og aftaler, der er til fordel for begge parter - kan forhandlingerne karakteriseres som integrative forhandlinger. Forhandlinger, der kun er til fordel for den ene part, karakteriseres som distributive forhandlinger (Walton \& McKersie 1965). Det kan være vanskeligt at etablere og fastholde integrative forhandlinger. En af besværlighederne kan være den koordinering af synspunkter, der sker på hver sin side af bordet - mellem de repræsentanter, der forhandler, og dem de forhandler for - de såkaldte intra-organisatoriske forhandlinger (ibid.). Især lokale tillidsrepræsentanter kan have vanskeligt ved at koordinere synspunkter blandt deres egne, da medlemmerne på en arbejdsplads ofte har meget forskellige ønsker til en aftale, men er organiseret i en flad struktur, hvor det kan være svært at skære igennem.

På mange punkter falder CSC-konflikten ikke umiddelbart uden for definitionen af den danske model. Der var tale om en konflikt i forbindelse med fornyelsen af to overenskomster mellem virksomheden CSC og fagforeningen PROSA, som var medlem af hver sin hovedorganisation (hhv. Dansk Erhverv og FTF). Alle de berørte medarbejdere var dækket af overenskomsterne og langt de fleste var medlem af PROSA. Og til trods for, at der var tale om en langtrukken konflikt, der berørte statslige IT-systemer, kom det ikke til politiske indgreb. PROSA mistede to af deres overenskomster på CSC, men CSC indgik en ny overenskomst med HK/ Privat ved konfliktens afslutning, således at alle medarbejdere forblev overenskomstdækkede.

En indledende analyse af, hvor CSC-konflikten kan siges at afvige fra definitionen på den danske model, peger dog på to afgørende undtagelser. For det første er der tale om en konfliktfyldt forhandlingsrelation, hvilket afviger fra det generelle billede af konsensusorienterede forhandlings- relationer på det danske arbejdsmarked (4. dimension). Et af de centrale spørgsmål er derfor, hvorfor parternes forhandlingsrelation ændrede sig. I forlængelse heraf er det også relevant at undersøge, om de konfliktende parter på CSC har overholdt de formelle spilleregler for konflikt undervejs i det langstrakte konfliktforløb. Konflikter har som tidligere nævnt aldrig været helt fraværende på det danske arbejdsmarked - hverken konflikter i forbindelse med fornyelse af overenskomster eller overenskomststridige arbejdsnedlæggelser. Derfor er en konflikt ikke nødvendigvis et brud med den danske model. Det afgørende er, om parterne overholder spillereglerne for konflikt, og om konflikten bidrager til, at parterne når i hus med et forlig. Det sidste skete ikke på CSC, da PROSA's medlemmer stemte forliget ned, og PROSA efterfølgende mistede deres overenskomst på CSC.

For det andet afviger CSC-konflikten i sit udgangspunkt fra den nationale samordning af overenskomster på det danske arbejdsmarked. Konflikten drejer sig om to virksomhedsoverenskomster, som har en asynkron udløbsdato (d. 1. juni) i forhold til resten af det private arbejdsmarked, hvor overenskomstfornyelsen ligger d. 1. marts. Det betyder, at forhandlingerne ligger på virksomhedsniveau, og at et eventuelt forlig ikke kan blive sammenkædet med resten af det private arbejdsmarked hos forligsmanden. Den danske model kan føres tilbage til det berømte Septemberforlig mellem hovedorganisationerne på det danske arbejdsmarked i 1899 (Due m.fl. 1993). Formålet med forliget var at løfte konflikterne ud af virksomhederne gennem en centralisering af forhandling og konfliktløsning. Centraliseringen kunne sikre arbejdsgiverne ro på virksomhederne til at udøve deres ledelsesret. Samtidigt kunne centraliseringen give arbejderne en forhandlingsstyrke, der matchede arbejdsgivernes. Begge sider 
havde derfor en interesse i en central koordinering af overenskomstforhandlingerne. Det er derfor et afgørende spørgsmål om afvigelsen fra denne centralisering bidrog til, at der ikke kom en forhandlingsmæssig løsning på konflikten på CSC.

I forlængelse heraf søges følgende to forskningsspørgsmål besvaret i analysen:

- Hvad bidrager til, at CSC og PROSA ikke kan oppebære en konsensusorienteret forhandlingsrelation?

- Kan den manglende centralisering af forhandlingerne bidrage til forklaringen af, at CSC og PROSA ikke får en forhandlingsmæssig løsning på konflikten?

\section{Metode}

Indeværende analyse bygger først og fremmest på 10 kvalitative interview med repræsentanter for medarbejdersiden og arbejdsgiversiden, som har været impliceret i konflikten på CSC. Mere specifikt bygger analysen på interview med følgende parter: to tidligere PROSA-tillidsrepræsentanter på CSC, to repræsentanter for PROSA på centralt niveau (PROSA-land), en repræsentant for CSC's ledelse, to repræsentanter for FTF, en repræsentant for Dansk Erhverv, en repræsentant for DA og en repræsentant for HK.

Alle interview blev gennemført efter konfliktens afslutning i perioden august-september 2011. Konflikten blev dog fulgt tæt på anden vis, mens den kørte i foråret 2011, som et forarbejde til interviewundersøgelsen. Forarbejdet bestod i en gennemlæsning af alle relevante aftale- og forligstekster, domme fra arbejdsretten, notater publiceret af parterne undervejs og bloggen på PROSA's hjemmeside, hvor medlemmerne kommenterede konfliktens forløb. Forarbejdet dannede grundlag for udformningen af den endelige interviewguide. Interviewene blev optaget og transskriberet i deres fulde længde og derpå analyseret ud fra en tematiseringsstrategi. Af hensyn til emnets karakter og den begrænsede personkreds, der var involveret i forhandlingerne på CSC, så blev alle citater, der ønskedes bragt i den endelige analyse, sendt til godkendelse hos de pågældende informanter. Dette medførte en række sproglige præciseringer, der dog ikke påvirkede citaternes overordnede indhold. Kun et citat blev afvist.

\section{Analyse}

Afsnittet om den danske model og dens centrale dimensioner gav en indledende sammenligning af CSC-konflikten og den danske model. Der blev identificeret to afgørende afvigelser fra den danske model, som mundede ud $\mathrm{i}$ formuleringen af to forskningsspørgsmål. Analysen af interviewene med konfliktens parter er struktureret i forhold til besvarelsen heraf. Første del koncentrerer sig om at identificere de forhold, der bidrog til, at CSC og PROSA ikke kunne oppebære en konsensusorienteret forhandlingsrelation. I anden del undersøges, om den manglende centralisering af forhandlingerne kan være en medvirkende årsag til, at parterne ikke fik en forhandlingsmæssig løsning på konflikten, og i givet fald hvordan.

\section{Fra konsensus til konflikt?}

CSC-konflikten beskriver på flere måder et usædvanligt forløb i nyere dansk arbejdsmarkedshistorie. Udover at der er tale om et meget langstrakt forløb, så er det også usædvanligt, at konflikten indledes med en lockout og afsluttes med, at arbejdsgiverne dømmes frigjort fra de berørte overenskomster. Flere kommentatorer har derfor stillet sig selv det spørgsmål, om konflikten og dens udfald primært er resultat af en bevidst strategi fra arbejdsgivernes side. Nogle har også 
i den offentlige debat sammenlignet forløbet med fænomenet 'union busting', som man kender fra USA (Larsen 2011). Begrebet henviser til, at nogle amerikanske arbejdsgivere bevidst modarbejder fagforeninger (ofte med støtte fra specialiserede advokatfirmaer) med det formål at få dem helt ud af deres virksomheder (Logan 2006). Der er dog flere forhold ved CSC-konflikten, der taler imod en sådan udlægning.

\section{CSC's forhandlingsposition og forhandlingsstrategi}

For det første sætter forløbet spørgsmålstegn ved, om parterne vitterligt havde en konsensusbaseret forhandlingsrelation i årene op til, at konflikten brød ud. Såvel repræsentanter for CSC's ledelse som PROSA's tidligere tillidsrepræsentanter på virksomheden fortæller, hvordan PROSA's medlemmer havde en meget stærk forhandlingsposition på virksomheden, som de brugte til at forhandle og fastholde nogle, for medarbejderne, gunstige ordninger i overenskomsten. Ledelsen ønskede at revidere ordningerne, fordi de ikke længere var tidssvarende i forhold til markedet, men de turde ikke tage et opgør med PROSA, fordi de var bange for, at PROSA så ville trække strejkevåbenet. Dette til trods for, at overenskomsterne indeholdt en fredsaftale, der betød, at PROSA's medlemmer kun kunne strejke på driften af de kørende systemer med tre måneders varsel. CSC servicerede en række centrale statslige kunder, som ikke ville kunne acceptere systemnedbrud, og det var derfor først efter en større outsourcing af jobfunktioner, at CSC opnåede en tilstrækkelig stærk forhandlingsposition til at kunne tage et opgør med PROSA:

"Det er nemt nok bare at saette en dato på, hvornår forhandlingerne startede. Set fra ledelsesside, har vi jo i mange år gerne villet gøre noget ved det her. Vi ville gerne gøre noget ved, at vi ikke var konkurrencedygtige, at vores løn ikke var performancebaseret men anciennitetsbaseret, og at vi havde nogle meget dyre tryghedsbestemmelser. Det handler om, at vi skal have en fleksibilitet, så vi kan udskifte arbejdsstyrken, når der er brug for det. Og vi havde ikke fleksibilitet i forhold til vores bemanding grundet de eksisterende tryghedsbestemmelser. Vi havde i mange år ikke kunnet tage fat om problemet, fordi vi ikke ønskede en konflikt. Hvis vi havde adresseret det, så vidste vi, det havde betydet konflikt, og vi var meget sårbare med de ydelser, vi sad med. Vi servicerede politiet, vi servicerede forsvaret, vi skulle sikre, at flyene blev holdt i luften, og vi havde ikke andre, der kunne hjoelpe os med det. Vi havde selvfølgelig prøvet at løse det her gennem årene på den almindelige måde. Vi har virkelig prøvet at sige: 'Det går ikke det her, vi er ikke konkurrencedygtige'. Min oplevelse har varet, at PROSA har sagt; 'Jamen, så må vi jo tage en konflikt på det'. Igennem de sidste to år har vi så outsourcet mere end 700 positioner til Indien og Litauen. Og det gjorde, at vi har vaeret i stand til at tage konflikten nu. Vi gjorde det helt efter bogen og startede et forhandlingsforløb, som vi har gjort så mange gange før, og som ikke førte til noget. I stedet for at give efter så sagde vi denne her gang: 'Nu kører vi videre'." (repræsentant for CSC's ledelse).

Ovenstående peger på, at både PROSA's og CSC's forhandlere har stillet hårdt mod hårdt i forhandlingerne alt afhængigt af, hvem der havde den stærkeste forhandlingsposition. En sådan forhandlingsstrategi kan hænge sammen med, at parterne såvel før som under/efter konflikten ikke har matchet hinanden i forhandlingsstyrke. Det er langt vanskeligere at etablere konsensusbaserede forhandlingsrelationer og integrative forhandlinger, der kommer begge parter til gode, hvis den ene part står meget stærkere 
end den anden (Walton \& McKersie 1965). Mens PROSA stod stærkt, har de afvist større ændringer i deres vilkår, hvilket har været en ulempe for CSC, og efter konflikten er medarbejderne på CSC nu dækket af en overenskomst med HK/Privat, som samlet set medfører en betydelig nedgang i de samlede løn- og arbejdsvilkår. Begge dele er udtryk for distributive forhandlinger - forhandlinger, der primært er til fordel for den ene part ved forhandlingsbordet (ibid.).

For det andet taler det forhold, at CSC og PROSA indgår et forlig d. 28. maj, imod en arbejdsgiverstrategi, der ligger i forlængelse af 'union busting'. CSC vælger meget sent i forløbet - og efter de har meddelt deres ønske om frigørelse fra overenskomsterne - at indgå forlig med PROSA's forhandlere. Det er først efter, at PROSA's medlemmer har stemt forliget ned, og frigørelsen senere bliver en realitet, at CSC vælger at indgå overenskomst med HK/Privat. Dette peger på, at CSC har ønsket at indgå overenskomst - og ønsket at indgå overenskomst med PROSA. Frigørelsen har ikke været et mål i sig selv:

"Da vi meddelte, at vi var frigjort fra overenskomsten, inviterede vi samtidig PROSA til nye forhandlinger om et nyt overenskomstgrundlag. Det var der også store dele af PROSA, der var interesseret $i$. I hvert fald kom PROSA - efter vi den 23. maj meddelte dem, at vi nu efter vores opfattelse var frigjort fra overenskomsten - til os og meddelte, 'vi vil gerne forhandle'. Vi havde nogle meget lange og hårde forhandlinger, men også konstruktive forhandlinger, der den 27. maj, som vi havde sat som deadline, faktisk forte frem til en aftale. Imidlertid blev det på et medlemsmøde den 30. maj med - som jeg har forstået det - et snoevert flertal besluttet, at man ikke ville sende aftalen til urafstemning blandt alle medlemmerne. Det undrede mig, at en roekke hardlinere blandt PROSA's medlemmer ønskede og fik held til at undgå en sådan afstemning" (repræsentant for Dansk Erhverv).

PROSA's forhandlingsposition og

forhandlingsstrategi

Da arbejdsgiverne skrider til lockout i februar 2011, og på den måde indleder den aktive konflikt, står de i den situation, at mellem 70 og 100 medarbejdere ikke har nogen fast arbejdsopgave på virksomheden. Disse medarbejdere er sandsynligvis ikke blevet afskediget, fordi det var alt for dyrt i forhold til de gældende tryghedsaftaler. En tidligere tillidsrepræsentant for PROSA fortæller, hvordan de pågældende medarbejdere i stedet sidder 'på bænken' og venter på, at det bliver deres tur til at arbejde - et fænomen, der også tidligere har været velkendt på CSC:

"Vi var godt klar over, at vi havde en hel del mennesker på boenken. Vi vidste godt, at det ville voere dem, firmaet lockoutede forst. (...) Baenken betyder, at du ikke umiddelbart er tilknyttet nogen arbejdsopgave. Det betyder, at du får løn, og du skal komme på arbejde hver dag, men du har ikke noget at lave. Du kan godt blive sat til ad hoc opgaver. Det gør de fleste, der sidder på boenken. Jeg har selv siddet på boenken $i$ en periode. Men du har ikke et fast tilknytningsforhold til en bestemt opgave. (...) Tallet har voeret lidt oppe og nede. Det meste af det her halvår [første halvår af 2011] - nu røg de jo så på lockout - har det vel ligget på et sted mellem 70 og 100" (tidligere PROSA-tillidsrepræsentant på CSC).

Det er tydeligt, at de gældende overenskomster ved konfliktens begyndelse primært var til fordel for PROSA's medlemmer, og at overenskomsterne medførte et stort pres på CSC's økonomi. Situationen er et resultat af, at PROSA's medlemmer har 
haft en stærk forhandlingsposition på virksomheden. Deres magtressourcer styrkes af, at deres arbejde har en stor samfundsmæssig betydning, og arbejdsgiverne dermed er bange for en konflikt (Due \& Madsen $2009,317)$. PROSA har haft en klar strategi om at udnytte den forhandlingsposition til at holde fast i nogle for branchen gunstige vilkår. Et eksempel på dette er, at man helt fremme i efteråret 2010 afviser CSC's ønske om at ændre overenskomsternes udløbsdato fra 1 . juni til 1. marts, hvor resten af det private arbejdsmarked (inklusive de øvrige medarbejdergrupper på CSC) fornyer deres overenskomster. PROSA har altså ønsket at fastholde den skæve overenskomstfornyelsesdato i forhold til de andre medarbejdergrupper på CSC og resten af det private arbejdsmarked, fordi man mente, man stadig stod stærkt og derved havde en fordel ved at gå solo. Mange af medlemmerne holder fast i denne overbevisning helt frem til slutningen af konfliktens forløb, hvor de stemmer forliget med CSC ned. De erkender først langt henne i forløbet eller efter konfliktens afslutning, at deres forhandlingsposition er svækket. En repræsentant for FTF påpeger, at den erkendelse falder for sent $\mathrm{i}$ forhold til at sikre et forlig - parterne står simpelthen for langt fra hinanden, til at man kan nå at omstille sig:

"Og som nogle af medlemmerne sagde: 'På den måde skød vi os selv i foden, for vi gjorde vores vilkår for gode. Det kunne vi måske dengang, men hvis vi bare havde kigget lidt frem, så er det et meget konkurrenceudsat område, vi arbejder på'. (...) Det tager jeg som et udtryk for det med at have det lange lys på: 'Hvad er det for en konkurrencesituation, man har på det her område?" (...) Og det er klart, at den korte periode, der løber fra april og frem til, at det hele brager sammen, det er mentalt for kort en proces til at omstille sig. Man har voeret vant til at have lønsystemer med mange trin, og det er meget svoert at forestille sig, at man skulle have noget helt andet" (reproesentant for FTF).

Der er imidlertid også andre forhold end den ændrede konkurrencesituation og den større mulighed for outsourcing af IT-opgaver, der bidrager til at svække PROSA's forhandlingsposition. Det er forhold, som strækker sig længere tilbage i tid, og som gør det til et risikabelt projekt for PROSA overhovedet at ende i en konflikt. Først og fremmest ligger der som tidligere nævnt en fredsaftale i overenskomsterne, som kun gør det muligt for PROSA's medlemmer at strejke på driften af de kørende IT-systemer med 3 måneders varsel. Det betyder, at PROSA først med stor forsinkelse kan ramme virksomheden, der hvor det gør rigtigt ondt - nemlig på driften af de følsomme, statslige IT-systemer. Dette giver CSC mulighed for at forberede sig på en strejke - at hente vikarer ind og oplære dem eller outsource opgaver. Alt i alt gør fredsaftalen det vanskeligt for PROSA at skabe en effektiv strejke. For det andet står PROSA ikke alene om at repræsentere ansatte på IT-området. HK har næsten siden PROSA's grundlæggelse været en konkurrent i forhold til at organisere de ansatte i den danske IT-branche. Det har givet anledning til konflikter imellem de to fagforeninger, og det giver samtidigt arbejdsgiverne et alternativt valg af forhandlingspartner. Landsoverenskomsten for IT-området mellem HK/Privat og Dansk Erhverv ligger som et reelt alternativ. Det svækker PROSA's magtressourcer, at de ikke har monopol på fagområdet, og at der er et konkurrerende forbund på IT-området (Due \& Madsen 2009, 317). Et fuldstændigt monopol ville have givet dem en stærkere forhandlingsposition. PROSA ville sandsynligvis også have haft lettere ved at etablere sympatistrejker, hvis ikke HK og PROSA stod i et konkurrenceforhold til hinanden. 
Ikke mindst fordi PROSA står i en anden hovedorganisation end HK. PROSA hører under FTF, hvis medlemmer (lærere, pædagoger m.fl.) kun vanskeligt kan ramme CSC med en sympatistrejke, mens HK hører under LO, hvis medlemmer ville kunne etablere sympatistrejker med en større effekt.

Med disse to forhold in mente - fredsaftalen og konkurrencen fra $\mathrm{HK}$ - så må konflikt siges at være en risikabel affære for PROSA. De har spillet højt spil ved at udnytte deres stærke forhandlingsposition på CSC, da deres markedsværdi var høj. Hvis de skulle ende i en konflikt - hvad de faktisk gjorde - ville ovennævnte forhold stille dem i en sårbar position.

\section{De formelle spilleregler for konflikt}

Det kommer til flere sammenstød mellem CSC og PROSA undervejs i konflikten, hvor de mener, at modpartens adfærd overskrider de formelle spilleregler for konflikt på det danske arbejdsmarked. Derfor indbringer de hinanden for arbejdsretten og faglig voldgift flere gange undervejs i forløbet, inden vi når til den afgørende dom om CSC's frigørelse fra overenskomsterne. Sagerne vedrører blandt andet, hvorvidt man kan strejke på opgaver eller personer i henhold til fredsaftalens bestemmelser (dom i arbejdsretten 24. marts), hvorvidt en uvarslet arbejdsnedlæggelse er overenskomststridig (dom i arbejdsretten 14. april), om CSC må ansætte vikarer under konflikten (faglig voldgift 24. maj), og om CSC må pålægge medarbejdere udtaget til strejke at oplære afløsere (dom i arbejdsretten d. 31. maj). PROSA's kritik går især på CSC's ansættelse af vikarer og oplevelsen af, at PROSA's medlemmer sættes til at oplære vikarer til konfliktramt arbejde. Omvendt fremhæver CSC den overenskomststridige arbejdsnedlæggelse blandt nogle af PROSA's medlemmer (der fulgte i kølvandet på vikarsagen) som en omgåelse af reglerne. Imidlertid følger begge parter de domme og afgørelser, der bliver truffet, således at konflikten ikke kører af sporet i forhold til de formelle spilleregler i den danske model. En repræsentant for HK udtrykker det på denne måde:

"Hvis man starter med den formelle tilgang, så er det jo arbejdsretten, der definerer, hvad der falder inden for modellens rammer. $\mathrm{Og}$ der har begge parter jo gjort ting, som faldt udenfor. Der var nogle folk, som ikke var omfattet af konflikten, der pludselig syntes, at de skulle vaere det, og de blev bortvist. Og det anerkendte arbejdsretten jo. Omvendt har virksomheden også foretaget sig ting, som arbejdsretten har sagt, at det måtte de ikke. Men hovedkonflikten har fulgt spillereglerne" (repræsentant for HK).

Selvom forhandlingerne mellem CSC og PROSA kan karakteriseres som distributive, så fører det altså ikke til, at nogen af parterne ser stort på spillereglerne for konflikt i den danske model. Begge parter træder ved siden af, men retter ind efter de kendelser, der afgives.

Forhandlingsstyrke, forhandlingsrelationer og aftaleindhold

Analysen af forhandlingsrelationerne mellem CSC og PROSA viser, at de langt fra har kunnet karakteriseres som konsensusbaserede i årene op til konflikten. Da det endelig kommer til konflikt, bidrager konflikten heller ikke til at sikre parterne et forlig. Hermed afviger forhandlingsrelationerne fra det generelle billede i den danske model. En vigtig årsag hertil er, at parterne ikke matcher hinanden i forhandlingsstyrke. PROSA havde i en længere periode op til konflikten en markant stærkere forhandlingsposition end CSC, hvorefter udviklingen vendte, og CSC stod langt stærkere end 
PROSA. Disse forskelle har først PROSA og siden CSC udnyttet til at få deres ønsker igennem. Forhandlingerne kan derfor i højere grad karakteriseres som distributive end integrative. Men hvordan ville parterne kunne sikre et bedre match i forhandlingsstyrken - og dermed også skabe bedre forudsætninger for integrative forhandlinger?

De fleste studier af kollektive forhandlinger tager udgangspunkt $i$, at arbejdsgiverne har en stærkere forhandlingsposition end arbejdstagerne. Denne magtasymmetri dannede også grundlag for udformningen af Septemberforliget i 1899, som blev grundstenen i den danske model. Centraliseringen af forhandlingerne sikrede arbejderne et ligeværdigt forhandlingsmandat i forhold til arbejdsgiverne, og samtidig fik arbejdsgiverne løftet konflikterne ud af virksomhederne, så de kunne udøve deres ledelsesret i fred (Due m.fl. 1993). I tilfældet med CSC-konflikten var det lønmodtagersiden, der stod stærkest i begyndelsen, mens arbejdsgiversiden stod stærkest fra konflikten og frem. Pointen er imidlertid den samme: En centralisering af forhandlingerne kunne have bidraget til at udjævne forskellen i forhandlingsstyrken. Spørgsmålet er derfor, om tilpasningen af overenskomsterne ville have haft et andet forløb, hvis forhandlingerne i højere grad havde været centraliserede. Hvis parterne over længere tid havde haft en mere ligeværdig forhandlingsstyrke, ville de så i højere grad have været i stand til at udvikle integrative løsninger på de ændrede markedsvilkår? Og hvis det var kommet til en konflikt, ville de så have kunnet komme i hus med en forhandlingsmæssig løsning? Disse spørgsmål vil vi forfølge i anden halvdel af analysen.

\section{Fravær af centralisering - fravær af forlig?}

Allerede i den indledende sammenligning af CSC-konflikten og definitionen på den danske model berørte vi det forhold, at forhandlingerne mellem CSC's ledelse og PROSA's tillidsrepræsentanter befinder sig på et mere decentralt niveau end hovedparten af forhandlingerne i det danske aftalesystem. I det følgende undersøges nærmere, hvor konflikten og de overenskomster, den vedrører, mere præcist kan siges at afvige fra den centrale koordinering af kollektive forhandlinger i den danske model - eller mere præcist formuleret den nationale samordning af overenskomster - og hvilken betydning det har for forhandlingsforløbet.

\section{Virksomhedsoverenskomster og lokal forhandlings- og konfliktret}

Først og fremmest afviger de berørte overenskomster fra den nationale samordning af forhandlingerne ved at være virksomhedsoverenskomster, der alene forhandles på lokalt niveau. PROSA's klubber har forhandlingsretten, og forhandlingerne sker direkte mellem CSC's ledelse og PROSA's lokale tillidsrepræsentanter. Selvom repræsentanter for det centrale PROSA (PROSA-land) og repræsentanter for parternes hovedorganisationer, FTF og Dansk Erhverv, også deltager i forhandlingerne, så er det de lokale repræsentanter, der har det sidste ord. Dette giver en række muligheder i forhold til at tilpasse overenskomsten til de lokale forhold, men det giver også en sårbarhed, da risikoen for at miste overenskomsten er større, hvis den står alene og ikke er en del af en sektoroverenskomst. Samtidig har PROSA-land ikke kompetence til at gå ind og stoppe konflikten på CSC, da forhandlingskompetencen ved overenskomstfornyelsen alene ligger hos PROSA's tillidsrepræsentanter på virksomheden. Det giver ifølge en repræsentant for FTF anledning til den skævhed, at det er de lokale repræsentanter for PROSA, der har forhandlings- og konfliktretten, men det er PROSA-land, der finansierer konflik- 
ten. Beslutning og betaling følges ikke ad, og hermed lægges der måske ikke tilstrækkeligt pres på forhandlerne i forhold til at finde en løsning:

"Man kan sige, at det kan voere svoert for en organisation SOm PROSA, der finansierer en konflikt, som vi har set på CSC. De har meget svaert ved at gå ind og stoppe konflikten eller sige, 'nu er det det her resultat, vi laver'. Det er suveroent de ansatte derude, der er organiseret $i$ de to klubber, der bestemmer, men PROSA finansierer. Man kan godt diskutere, om det er hensigtsmaessigt i forhold til sådan en langvarig konflikt, som vi ser her" (repræsentant for FTF).

\section{Asynkron udløbsdato}

En anden - og måske mere alvorlig - afvigelse fra den nationale samordning af overenskomsterne ligger i det faktum, at PROSA's overenskomster har en anden udløbsdato end de øvrige overenskomster på det private arbejdsmarked. PROSA's overenskomster udløber 1. juni, mens resten af overenskomstfornyelserne sker pr. 1. marts. Dette betyder, at forlig ikke kan tages med i forligsmandens samlede mæglingsforslag og sendes til en samlet urafstemning. En tidligere PROSA-tillidsrepræsentant påpeger, at den asynkrone udløbsdato har givet dem mange forhandlingsmæssige fordele. Det er blandt andet baggrunden for, at de har kunnet få forhandlet tryghedsaftalerne ind i overenskomsterne. Det betyder også, at de har kunnet lave nogle overenskomster, som var tæt på medlemmerne og deres behov:

"Der vil jeg sige, at vi har vist rettidig omhu ved allerede $i$ 1980'erne at få lavet en tryghedsaftale, som netop kunne voere et voern mod, at alle vores opgaver ryger ud til lande som Indien. Det er jo et meget godt eksempel på sådan nogle specifikke ting, man kan tage op i overenskomstforhandlingerne, når man ikke er en del af bunkebrylluppet. (...) Det betyder rigtig meget for os, at vi har det noerdemokrati. Det er også derfor, at folk kommer til medlemsmøderne herude, og at folk engagerer sig vildt $i$ det her, fordi det er så toet på os" (tidligere PROSA-tillidsrepræsentant på CSC).

Men den asynkrone dato viser sig også at have en alvorlig bagside. Da CSC ønsker at revidere deres overenskomster med PROSA, kommer PROSA's medlemmer til at stå alene i deres kamp, fordi deres overenskomster skal fornyes før overenskomsterne for de andre medarbejdergrupper på CSC. Samtidig viser det sig overordentligt vanskeligt for PROSA's forhandlere at etablere et ja blandt medlemmerne til det forlig, de har indgået med CSC. Hvis forliget havde været en del af et samlet mæglingsforslag, var det måske ikke blevet stemt ned. Dette vil vi se nærmere på i de følgende afsnit.

\section{Flad struktur og intern uenighed}

Fokuserer man på de interne forhandlinger på medarbejderside undervejs i konflikten de såkaldt intra-organisatoriske forhandlinger - finder vi også her en afvigelse fra det generelle billede i den danske model (Walton \& McKersie 1965). Beslutningsstrukturen i de lokale PROSA-klubber på CSC og den samlede lokale bestyrelse er kendetegnet ved at være stærkt decentraliseret. Langt de fleste beslutninger skal til afstemning blandt medlemmerne:

"Vi har nogle vedtoegter, der siger, at hver gang vi skal traeffe vigtige beslutninger i en eller anden form for konflikt eller forhandling, så skal det forbi et medlemsmøde. Og vi har brugt mange medlemsmøder $i$ denne her periode, og de har voeret godt besøgt. Det 
betyder, at hvis vi skal troeffe en beslutning: 'Nu ligger der et forslag, skal det saettes til urafstemning, eller skal det ikke', så er det medlemsmødet, der bestemmer det fuldstoendig suveroent. (...) Stort set alle beslutninger er taget på medlemsmøderne, og det har ligget toet. Og vi gør rigtig meget for at orientere, så vi når ud til alle mennesker, og de i god tid ved, at nu er mødet der, og de ved, hvad indholdet af mødet er, og hvad det er, de skal tage stilling til" (tidligere PROSAtillidsrepræsentant på CSC).

Det er ikke overraskende, at strukturen er så decentral, når der samtidig er tale om meget decentrale forhandlinger. Mange studier af kollektive forhandlinger peger på, at selvom det ofte er arbejdsgiverne, der fastlægger, hvilket niveau forhandlingerne foregår på, så har dette niveau betydning for den interne beslutningsstruktur blandt både arbejdsgiverne og lønmodtagerne (Clegg 1976; Sisson 1987). Ligger forhandlingerne på centralt niveau, så er forhandlingskompetencen centraliseret i både arbejdsgiverorganisationen og i fagforeningen. Ligger forhandlingerne lokalt, så er forhandlingskompetencen ofte placeret hos den enkelte arbejdsgiver og den lokale fagforening eller tillidsrepræsentant.

Problemet med en meget decentral beslutningsstruktur kan være, at der ofte er meget uenighed internt på medarbejderside, når der forhandles med ledelsen. Dette følger af den flade struktur, der ofte er blandt medarbejderne på en arbejdsplads.

Tillidsrepræsentanter har derfor i udgangspunktet altid haft sværere ved at koordinere de intra-organisatoriske forhandlinger blandt deres egne end ledelsesrepræsentanter, der ofte repræsenterer toppen af et hierarki (Walton \& McKersie 1965). Hvis man ikke har nogle mekanismer, der kan skære igennem uenigheden, så kan det derfor være svært for forhandlere på medarbej- derside at skabe et forlig med ledelsen, som flertallet af medarbejderne kan leve med.

Man må sige, at uenigheden var stor internt blandt PROSA's medlemmer undervejs i konflikten på CSC. Da PROSA's forhandlere indgår forlig med CSC's ledelse i slutningen af maj, hvor CSC reelt har udtrykt ønske om at frigøre sig helt fra overenskomsten, stemmes der på et medlemsmøde knebent nej til at sende forliget til urafstemning. Da forligsmanden senere sender et næsten identisk mæglingsforslag til urafstemning er resultatet også et knebent nej. Medlemmer er stærkt splittede i forhold til at sige ja til forliget:

"Der var simpelthen - isaer til sidst - forskellige synspunkter på, hvad der kunne lade sig gøre. Der var en lille gruppe, som i lang tid havde syntes, at vi nok skulle straekke os loengere for at blive enige med CSC. Men de fleste af dem, der sagde ja - de var jo ikke synske - de gjorde det, fordi de sagde 'jamen, hvad er alternativet?'. Det var ikke sådan, at den store gruppe sagde ja, fordi det var et godt forslag, men fordi de syntes, det var det bedst mulige forslag, og risikoen ved et nej var for stor. (...) De, der sagde nej, havde forskellige holdninger. Der var nogle, der sagde: 'vi vil hellere dø med støvlerne på'. Men det er klart, at de fleste virkelig troede, at så kunne man få et bedre resultat - $i$ hvert fald lidt bedre" (repræsentant for PROSA-land).

Uenigheden tyder på, at der stadig er en stor gruppe af PROSA's medlemmer, som mener, at man har en forholdsvis stærk forhandlingsposition - selv da CSC's frigørelse fra overenskomsten ser ud til at være en reel trussel. Denne uenighed får også konsekvenser ved selve forhandlingsbordet. Den lokale bestyrelse, som fører forhandlingerne, er også internt uenige - og den er tilmed tvunget til at koordinere sine forhandlingsmæssige udspil med en baggrundsgruppe 
med skiftende deltagere. Dette gør det meget vanskeligt for forhandlerne at etablere et kontinuert og troværdigt forhandlingsmandat:

\begin{abstract}
"Vores problem var, at vi var meget uenige $i$ bestyrelsen. Ud over bestyrelsen, som i virkeligheden noesten er det samme som forhandlingsudvalget, så har vi også det, der hedder en baggrundsgruppe. En baggrundsgruppe er sådan set åben for alle på det tidspunkt, man nedsaetter den. Meningen med en baggrundsgruppe er, at forhandlerne skal have et forum, de kan gå til og fra, mens de forhandler og sige: 'Nu snakker vi om det her, er det en vej, vi kan tillade os at gå?'. Eller: 'Nu siger ledelsen sådan, kan vi tillade os at sige sådan i stedet for?'. Så man har et eller andet at spille bold op ad. (...) Vores problem var, at vi denne gang havde en baggrundsgruppe, hvor der var meget stor udskiftning, og derfor var det ikke de samme mennesker, man spillede bold op ad hver gang. Det betød, at vi fik forskellige beslutninger. Det, der var okay den ene dag, det var ikke okay tre dage senere. Det var umuligt at arbejde med" (tidligere PROSA-tillidsrepræsentant på CSC).
\end{abstract}

\section{Centraliseringsgrader og forligsmuligheder}

Samlet set må overenskomstfornyelsen mellem CSC og PROSA, som dannede grundlag for konflikten i foråret 2011, siges at ligge på et noget mere decentralt niveau end det generelle billede af kollektive forhandlinger i den danske model. Due m.fl. (1993) skelner mellem syv forskellige grader af centralisering, når det gælder overenskomstforhandlinger i Danmark (se Figur 2). Der er flere forhold, der er afgørende for, om forhandlingerne er centraliserede eller ej: Hvem der forhandler, om hovedorganisationerne medvirker i forhandlingerne og om forligsinstitutionen kan sammenkæde mæglingsforslag. Den nationale samordning af overenskomster henviser til kombinationen af centrale forhandlinger og forligsmandens mulighed for at samordne mæglingsforslag. Dette svarer i figuren til centraliseringsgrad 6 .

Figur 2. Centraliseringsgrader i den danske model

1 Decentrale forhandlinger

2 Decentrale forhandlinger, der løses under hovedorganisationernes medvirken

3 Centraliserede forhandlinger, hvor hovedorganisationerne løser generelle spørgsmål for hele LO/DA området

4 Decentrale forhandlinger + sammenkædning i forligsinstitutionen

5 Decentrale forhandlinger under hovedorganisationernes medvirken + sammenkædning i forligsinstitutionen

6 Centraliserede forhandlinger, der løses under forligsinstitutionens medvirken inklusiv sammenkædning af mæglingsforslag

7 Politiske indgreb

Kilde: Due m.fl. 1993, 169.

Overenskomstfornyelsen på CSC når kun til centraliseringsgrad 2. Der er tale om decentrale forhandlinger, der løses under hovedorganisationernes medvirken, men forligsmanden har ikke mulighed for at sammenkæde eventuelle forlig i et samlet mæglingsforslag. Hvis overenskomsterne havde haft samme udløbsdato som på resten af det private arbejdsmarked, så havde der været tale om centraliseringsgrad 4 . Forliget mellem PROSA og CSC kunne hermed have indgået i et samlet mæglingsforslag fra forligsmanden, der blev stemt hjem via en samlet urafstemning.

Dette ville imidlertid ikke nødvendigvis ændre ved niveauet for forhandlingerne og den interne struktur i PROSA. Hvis PROSA skal ændre sin beslutningsstruktur i en mere centraliseret retning, så kræver det måske et krav fra arbejdsgiverne om, at forhandlingerne i højere grad ligger på orga- 
nisations- eller hovedorganisationsniveau. Det er meget svært for en fagforening selv at ændre sin interne beslutningsstruktur. Hvorfor skulle medlemmerne selv stemme for at afgive magt? PROSA kunne derfor let have kommet til at kæmpe med den interne beslutningsstruktur og interne uenighed i fremtidige forhandlingsrunder, selv hvis medlemmerne havde stemt forliget hjem.

\section{Opsamling}

Analysen af CSC-konflikten tager udgangspunkt $\mathrm{i}$ to former for afvigelser fra definitionen på den danske model - fravær af konsensusbaserede forhandlingsrelationer og fravær af en national samordning af overenskomsterne. Første del af analysen viser, at konsensus sandsynligvis ikke blot var fraværende i forbindelse med konflikten men også før konflikten. Dette kan skyldes, at de forhandlende parter - CSC's ledelse og PROSA's tillidsrepræsentanter på CSC både før og efter konflikten har haft meget forskellige forhandlingsstyrker. Hvor PROSA havde en meget stærkere forhandlingsposition end CSC inden konflikten, så er det lige omvendt, da konflikten bryder ud (og måske endda lidt før dette). Dette skyldes ikke blot, at der er kommet større konkurrence på IT-arbejdskraft end tidligere, hvilket svækker PROSA's magtressourcer. PROSA's forhandlingsstrategi har på flere måder været risikabel allerede fra begyndelsen, fordi de ikke har fuldstændigt monopol på deres fagområde. HK udgør en stærk konkurrent i forhold til organisering af ansatte i ITbranchen, og der ligger en landsoverenskomst på IT-området mellem HK/Privat og Dansk Erhverv, som er et reelt alternativ til CSC's overenskomster med PROSA. PROSA's magtressourcer på CSC står og falder derfor med CSC's afhængighed af de ansattes kompetencer. Anden del af analysen viser, at de store forskelle i CSC's og PROSA's for- handlingsstyrke ikke blot får betydning for deres forhandlingsrelationer og indholdet af deres overenskomster. Forskellene får også afgørende betydning for konfliktens opståen, dens forløb og udfald. Dette skyldes at overenskomstforhandlingerne mellem CSC og PROSA på flere måder er stærkt decentraliserede, og mekanismerne længere oppe i det danske aftalesystem ikke tilstrækkeligt effektivt kan bidrage til at sikre en forhandlingsmæssig løsning. Der er tale om virksomhedsoverenskomster med asynkrone udløbsdatoer i forhold til resten af det private arbejdsmarked, og selvom hovedorganisationerne medvirker i forhandlingerne, er det CSC's ledelse og de lokale tillidsrepræsentanter, der har det sidste ord. Samtidig følger koordineringen af forhandlingerne internt i PROSA en meget flad struktur, der næsten lægger forhandlingsmandatet helt ud på gulvet i virksomheden.

Den centralisering af kollektive forhandlinger og konfliktløsning i den danske model, som blev grundlagt med Septemberforliget i 1899, skulle netop bidrage til at skabe balancerede aftaler på det danske arbejdsmarked, som kunne holde konfliktniveauet nede. Det er svært for parterne på CSC at skabe balancerede løsninger, fordi de på mange måder står uden for den centralisering, og forskellen i forhandlingsstyrken dermed får frit spil. Forhandlingerne bevæger sig aldrig fra distributive til integrative. Samtidig betyder den manglende centralisering af forhandlingerne, at forhandlingskompetencen i PROSA ikke tvinges til en mere central placering i den interne struktur, der bedre kan koordinere forhandlingerne $i$ en konfliktsituation. Hermed får uenigheden på medarbejderside et for stort spillerum. Selvom parternes forhandlere faktisk når til et forlig, så får de ikke en forhandlingsmæssig løsning - den bliver stemt ned af de fortsat stærkt splittede medlemmer. 


\section{Konklusion og diskussion}

Analysen viser, at de store forskelle i forhandlingsstyrke mellem CSC's ledelse og PROSA's tillidsrepræsentanter bidrager til, at parterne har vanskeligt ved at etablere en konsensusorienteret forhandlingsrelation. Hvis forhandlingerne i højere grad havde været centraliserede, er det imidlertid ikke sikkert, at det ville have været så vanskeligt. En større centralisering af forhandlingerne kunne have udjævnet forskellene i forhandlingsstyrke så tilpas meget, at parterne lang tid før konflikten kunne have etableret konsensusorienterede forhandlinger og udviklet overenskomster, der i højere grad tilgodeså begge parter. Hvis det alligevel var kommet til konflikt, ville sandsynligheden for en forhandlingsmæssig løsning også have været større. Derfor forekommer CSCkonfliktens afvigelse fra den dimension af den danske model, der har at gøre med centraliseret forhandling og konfliktløsning (den nationale samordning af overenskomster), at være den vigtigste i forhold til konfliktens forløb og udfald. Uanset graden af centralisering havde PROSA's medlemmer nok skullet justere deres løn- og arbejdsvilkår i takt med arbejdsmarkedets udvikling inden for IT-området, men en højere grad af centralisering havde måske skabt fundamentet for en løbende og mere jævn tilpasning, og PROSA havde måske kunnet undgå helt at miste de pågældende overenskomster på CSC.

Spørgsmålet er derfor, om det er en central lære af CSC-konflikten, at forhandlinger bør ligge på sektorniveau - og ikke på virksomhedsniveau - hvis løn- og arbejdsvilkår skal balanceres i tide. Det er klart, at en virksomhedsoverenskomst giver større mulighed for at tilpasse vilkårene til såvel virksomhedens som medarbejdernes behov for at finde kreative løsninger på globaliseringens udfordringer. En virksomhedsoverenskomst kan også give medarbejdere en større følelse af ejerskab i forhold til overenskomsten og gøre det lettere for fagforeningen at mobilisere medlemmerne. Problemet med en virksomhedsoverenskomst er imidlertid, at den stærke lettere vinder over den svage - især hvis det ikke er en 1. marts overenskomst med udløb som resten af det private arbejdsmarked. Dermed kan forhandlingerne føre til store udsving i løn- og arbejdsvilkår, eller de kan resultere i, at man mister overenskomsten som i tilfældet med konflikten på CSC. Udsvingene i løn- og arbejdsvilkår må forventes at være mindre i en sektoroverenskomst, som fornys samtidigt med resten af det private arbejdsmarked. Den stærke opnår måske mindre, end hvis der havde været tale om en virksomhedsoverenskomst, men omvendt er det også en forsikring i forhold til, når den stærke engang selv bliver svag. Det er dog her vigtigt at pointere, at langt størstedelen af det danske arbejdsmarked er reguleret via overenskomster på sektorniveau. Rene virksomhedsoverenskomster som PROSA's overenskomster på CSC har kun begrænset udbredelse.

Mere generelt kan man sige, at konflikten peger på et vigtigt dilemma for den danske fagbevægelse i de kommende år. Spørgsmålet er, hvordan fagforeningerne kan forene en central koordinering af overenskomsterne med en fortsat opbakning fra medlemmerne, når løn- og arbejdsvilkår stagnerer eller forringes. Organisationsgraden blandt danske lønmodtagere falder, og fagforeningerne oplever i stigende grad vanskeligheder med at rekruttere og fastholde medlemmer (Due m.fl. 2010). Udviklingen kan pege på en af bagsiderne ved en centralisering af forhandlingerne. Medlemmerne kan have svært ved at se sig selv og deres behov reflekteret i centralt fastsatte overenskomster, og dette kan sætte et afgørende aspekt af den danske model - de høje organisationsprocenter - under pres. En af PROSA's erfaringer er, at det er lettere at mobilisere 
og engagere medlemmerne, jo tættere overenskomsten er på den enkelte arbejdsplads. Udfordringen for fagbevægelsen bliver derfor at kombinere den centrale koordinering af forhandlingerne med en mobilisering af medlemmerne. Her kunne man med fordel skele til industriens overenskomster, der som tidligere nævnt har udviklet sig til egentlige rammeoverenskomster. Den centrale koordinering bevares, men under forudsætning af lokal enighed har ledere og tillidsrepræsentanter faktisk mulighed for at udvikle mini-overenskomster på den enkelte virksomhed, som afviger fra sektoroverenskomsten på en lang række punkter (Larsen \& Jensen 2003; Ilsøe 2009). Hermed er der potentiale for, at lederne opnår den fleksibilitet, konkurrencesituationen kræver, og at medarbejdere kan genfinde sig selv i de vilkår, der gælder på deres arbejdsplads, samtidig med at den centrale koordinering af forhandlingerne bevares.

\section{Referencer}

Baadsgaard, Mikkel \& Gyrithe R. Hansen (2011): Udvikling i it-beskoeftigelsen, København, Arbejderbevægelsens Erhvervsråd. Bjørsted, Erik \& Niels S. Knigge (2009): Krisen har bidt sig godt fast i IT-branchen, København, Arbejderbevægelsens Erhvervsråd.

Clegg, Hugh A. (1976): Trade Unionism under Collective Bargaining: A Theory based on Comparisons of Six Countries, Oxford, Blackwell.

Contractor, Farok J. m.fl. (red.) (2011): Global Outsourcing and Offshoring - An Integrated Approach to Theory and Corporate Strategy, Cambridge, Cambridge University Press.

CSC (2011): CSC forhandler ny overenskomst med PROSA, Pressemeddelelse januar 2011, København, CSC, www.csc.dk.

DA (2011a): Konfliktstatistik 1. kvartal 2011, København, DA.

DA (2011b): Lønstatistik 3. kvartal 2011, København, DA.

Due, Jesper, Jørgen S. Madsen \& Mie D. Pihl (2010): Udviklingen $i$ den faglige organisering: årsager og konsekvenser for den danske model, LO-dokumentationen nr. 1, København, LO.

Due, Jesper \& Jørgen S. Madsen (2009): Forligsmagere og forumshoppere. Analyse af OK 2008 $i$ den offentlige sektor, København, Jurist- og Økonomforbundets Forlag.

Due, Jesper \& Jørgen S. Madsen (2006): Fra storkonflikt til barselsfond. Den danske model under afvikling eller fornyelse, København,
Jurist- og Økonomforbundets Forlag.

Due, Jesper \& Jørgen S. Madsen (1996): Forligsmagerne. De kollektive forhandlingers sociologi, København, Jurist- og Økonomforbundets Forlag.

Due, Jesper, Jørgen S. Madsen \& Carsten S. Jensen (1993): Den danske model. En historisk sociologisk analyse af det danske aftalesystem, København, Jurist- og Økonomforbundets Forlag.

Hansen, Nana W., Åsmund A. Seip \& Line Eldring (red.) (2010): Rekruttering av kompetansearbeidskraft fra tredjeland til Norden, København, Nordisk Ministerråd.

Ilsøe, Anna (2009): Decentralisering i praksis: En spørgeskemaundersøgelse af lokalaftaler om løn og arbejdsvilkår i industrien, FAOS Forskningsnotat nr. 103, København, Københavns Universitet.

Larsen, Allan (2011): It-virksomhed anklages for at tryne fagbevægelsen, i Ugebrevet A4, nr. 10, 14. marts.

Larsen, Anders S. \& Jesper J. Jensen (red.) (2003): Industriens lokalaftaler. Vejledning $i$ indgåelse, administration og opsigelse af lokalaftaler, København, DI.

Logan, John (2006): The Union Avoidance Industry in the United States, i British Journal of Industrial Relations, 44, 4, 651-675.

Lundrup, Dan (2008): De satans typografer, Rødovre, Forlaget Sohn.

PROSA (2011): Fakta om konflikten på CSC, Kø- 
benhavn, PROSA, www.prosa.dk.

Navrbjerg, Steen E., Trine P. Larsen \& Mikkel

M. Johansen (2010): Tillidsreproesentanten $i$

det 21. århundrede: sammenfatning af TR-

undersøgelsen 2010, København, LO.

Sisson, Keith (1987): The Management of Collec- tive Bargaining. An International Comparison, Oxford, Blackwell.

Walton, Richard E. \& McKersie, Robert B.

(1965): A Behavioral Theory of Labor Negotiations - An Analysis of a Social Interaction System, New York, McGraw-Hill.

Anna Ilsøe, cand.scient.soc., ph.d., er adjunkt ved Forskningscenter for Arbejdsmarkedsog Organisationsstudier (FAOS), Sociologisk Institut, Københavns Universitet e-mail: ai@faos.dk

\section{CALL FOR PAPERS}

\section{FRA TR TIL HR? Arbejdsmiljøets rolle i moderne arbejdspladsudvikling}

Temanummer - Tidsskrift for Arbejdsliv, nr. 1, 2013

Tidsskrift for Arbejdsliv inviterer bidrag, der udforsker arbejdsmiljøets rolle i moderne arbejdspladsudvikling. Vi er særligt interesserede $\mathrm{i}$ analyser af forandringer i de institutionelle rammer for og praksisser omkring varetagelse af arbejdsmiljøarbejdet, herunder ændringer i aftalesystem, lovgivning og daglig praksis på arbejdspladserne. Kan man tale om en bevægelse af arbejdsmiljøarbejdet fra sikkerhedsorganisation over samarbejdsudvalg til HR-afdelingen? Hvilken betydning har bevægelserne for magtforhold og ikke mindst på hvilke spørgsmål og temaer som arbejdsmiljøarbejdet kommer til at omhandle?

Bidrag kan behandle teoretiske som empiriske problemstillinger, konkrete cases som sammenlignende analyser samt analyser, der anlægger et historisk perspektiv på arbejdsmiljøets rolle i moderne arbejdspladsudvikling.

Abstract på max. 500 ord indsendes til gleerup@ruc.dk inden d. 1. august 2012. Artikler bedes følge tidsskriftets guideline. Læs mere om call for papers og se forfattervejledning på http:// www.nyt-om-arbejdsliv.dk/.

Med venlig hilsen

Temaredaktionen

Peter Hagedorn-Rasmussen, Kubix (phr@kubix.dk); Janne Gleerup, RUC (gleerup@ruc.dk); Anders Bojesen, HK/Stat (44abo@hk.dk)

Deadline for abstracts: 1. august 2012

Deadline for artikler: 15. september 2012 